\title{
TANK 40 FINAL SB5 CHEMICAL CHARACTERIZATION RESULTS PRIOR TO NP ADDITION
}

\author{
C. J. Bannochie \\ D. R. Click
}

February 2009

Savannah River National Laboratory Savannah River Nuclear Solutions

Aiken, SC 29808

Prepared for the U.S. Department of Energy Under

Contract Number DE-AC09-08SR22470

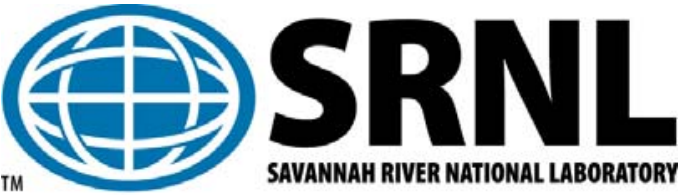


SRNL-STI-2009-00060

Revision 0

\section{DISCLAIMER}

This work was prepared under an agreement with and funded by the U.S. Government. Neither the U. S. Government or its employees, nor any of its contractors, subcontractors or their employees, makes any express or implied:

1. warranty or assumes any legal liability for the accuracy, completeness, or for the use or results of such use of any information, product, or process disclosed; or 2. representation that such use or results of such use would not infringe privately owned rights; or

3. endorsement or recommendation of any specifically identified commercial product, process, or service.

Any views and opinions of authors expressed in this work do not necessarily state or reflect those of the United States Government, or its contractors, or subcontractors.

\section{Printed in the United States of America}

Prepared For

U.S. Department of Energy 
Key Words: DWPF, SB5, Tank 40, Waste Acceptance

Retention: PERMANENT

\title{
TANK 40 FINAL SB5 CHEMICAL CHARACTERIZATION RESULTS PRIOR TO Np ADDITION
}

\author{
C. J. Bannochie \\ D. R. Click
}

February 2009 


\section{REVIEWS AND APPROVALS}

\section{AUTHOR(S):}

C. J. Bannochie, Process Engineering Technology

Date

D. R. Click, Analytical Development

Date

\section{TECHNICAL REVIEWERS:}

D. C. Koopman, Process Engineering Technology

Date

N. E. Bibler, Process Engineering Technology

Date

\section{APPROVERS}

C. C. Herman, Manager, Process Engineering Technology

Date

S. L. Marra, Manager, Research Programs, E\&CPT

Date

J. E. Occhipinti, Manager, Waste Solidification Engineering

Date 


\section{EXECUTIVE SUMMARY}

A sample of Sludge Batch 5 (SB5) was pulled from Tank 40 in order to obtain radionuclide inventory analyses necessary for compliance with the Waste Acceptance Product Specifications (WAPS) ${ }^{1}$. This sample was also analyzed for chemical composition including noble metals. Prior to radionuclide inventory analyses, a final sample of the $\mathrm{H}$-canyon $\mathrm{Np}$ stream will be added to bound the $\mathrm{Np}$ addition anticipated for Tank 40. These analyses along with the WAPS radionuclide analyses will help define the composition of the sludge in Tank 40 that is currently being fed to DWPF as SB5.

At the Savannah River National Laboratory (SRNL) the 3-L Tank 40 SB5 sample was transferred from the shipping container into a 4-L high density polyethylene vessel and solids allowed to settle overnight. Supernate was then siphoned off and circulated through the shipping container to complete the transfer of the sample. Following thorough mixing of the 3-L sample, a $239 \mathrm{~g}$ sub-sample was removed. This sub-sample was then utilized for all subsequent analytical samples.

Eight separate aliquots of the slurry were digested, four with $\mathrm{HNO}_{3} / \mathrm{HCl}$ (aqua regia ${ }^{2}$ ) in sealed Teflon ${ }^{\circledR}$ vessels and four in $\mathrm{Na}_{2} \mathrm{O}_{2}$ (alkali or peroxide fusion ${ }^{3}$ ) using $\mathrm{Zr}$ crucibles. Due to the use of $\mathrm{Zr}$ crucibles and $\mathrm{Na}$ in the peroxide fusions, $\mathrm{Na}$ and $\mathrm{Zr}$ cannot be determined from this preparation. Additionally, other alkali metals, such as $\mathrm{Li}$ and $\mathrm{K}$ that may be contaminants in the $\mathrm{Na}_{2} \mathrm{O}_{2}$ are not determined from this preparation. Three Analytical Reference Glass $-1^{4}$ (ARG-1) standards were digested along with a blank for each preparation. The ARG-1 glass allows for an assessment of the completeness of each digestion. Each aqua regia digestion and blank was diluted to $1: 100 \mathrm{~mL}$ with deionized water and submitted to Analytical Development (AD) for inductively coupled plasma - atomic emission spectroscopy (ICPAES) analysis, inductively coupled plasma - mass spectrometry (ICP-MS) analysis of masses 81-209 and 230-252, and cold vapor atomic absorption (CV-AA) analysis for Hg. Equivalent dilutions of the peroxide fusion digestions and blank were submitted to AD for ICP-AES analysis.

Tank 40 SB5 supernate was collected from a mixed slurry sample in the SRNL Shielded Cells and submitted to AD for ICP-AES. Weighted dilutions of slurry were submitted for ion chromatography (IC), total inorganic carbon/total organic carbon (TIC/TOC), and total base analyses.

The following conclusions were drawn from the analytical results reported here:

- The elemental ratios of the major elements for the SB5 WAPS sample, whose major Tank 51 Qualification sample component underwent Al dissolution, are similar to those measured for the SB4 WAPS sample.

\footnotetext{
${ }^{1}$ Office of Environmental Restoration and Waste Management, Waste Acceptance Product Specifications for Vitrified High-Level Waste Forms, US DOE Document DOE/EM-0093, Rev. 2, (12/96).

${ }^{2}$ Coleman, C. J. Aqua Regia Dissolution of Sludge for Elemental Analysis, Manual L16.1, Procedure ADS-2226, Rev. 7, Savannah River Site, Aiken, SC 29808 (2008).

${ }^{3}$ Coleman, C. J. Alkali Fusion Dissolutions of Sludge and Glass for Elemental and Anion Analysis, Manual L16.1, ADS-2502, Rev. 6, Savannah River Site, Aiken, SC 29808 (2008).

${ }^{4}$ Smith, G. L. Characterization of Analytical Reference Glass - 1 (ARG-1), PNL-8992, Pacific Northwest (National) Laboratory, Richland, WA (1993).
} 
- The elemental composition of this sample and the analyses conducted here are reasonable and consistent with DWPF batch data measurements in light of DWPF pre-sample concentration and SRAT product heel contributions to the DWPF SRAT receipt analyses.

- Fifty percent of the sulfur in the SB5 WAPS sample is insoluble, and this represents a significantly larger fraction than that observed in previous sludge batches.

- The noble metal and Ag concentrations predicted from the measured values for the Tank 51 Confirmation sample and Tank 40 SB4 WAPS sample using a two-thirds Tank 51, one-third Tank 40 heel blend ratio used to arrive at the final SB5 composition, agree with the values for the Tank 40 SB5 WAPS sample measured for this report. 
TABLE OF CONTENTS

EXECUTIVE SUMMARY iv

LIST OF TABLES vii

LIST OF ACRONYMS/Abbreviations viii

1.0 INTRODUCTION AND BACKGROUND 1

2.0 APPROACH AND RESULTS 3

2.1 Analytical Methods

2.2 Results

3

3.0 DISCUSSION

3.1 Carbonate

3.2 Anion Comparison

3.3 Sulfur

3.4 Elemental Ratios

3.5 Noble Metal Ratios

4.0 CONCLUSIONS

5.0 REFERENCES 


\section{LIST OF TABLES}

Table 2-1. Weight Percent Solids and Density for Tank 40 SB5 Samples and DWPF SRAT Receipt Batch 472 [Number of Samples Included in Average].

Table 2-2. Supernate Analyses for Tank 40 SB5 Samples [Number of Samples Included in Average].

Table 2-3. Carbon Analysis for Tank 40 SB5 Samples [Number of Samples Included in Average] (mg C/kg slurry) ................................................................................... 5

Table 2-4. Base Analysis for Tank 40 SB5 Samples [Number of Samples Included in Average] (mol/kg slurry)

Table 2-5. Elemental Concentrations* in Tank 40 SB5 Samples in Wt \% of Total Solids (\%RSD) [Number of Samples Included in Average]

Table 2-6. Noble Metal Fission Products and Silver Concentrations in Tank 40 SB5 WAPS, Qualification and Confirmation Samples in Wt \% of Total Solids (\%RSD)....................... 8

Table 3-1. Comparison of Elemental Ratios for Major Insoluble Elements in the Tank 40 SB4 and SB5 Samples with DWPF Batch 472 SRAT Receipt Data

Table 3-2. Fission Yield Ratios and Measured Noble Metal Ratios in Various SB4 and SB5 Samples

Table 3-3. Predicted versus Measured SB5 WAPS Noble Metal Concentrations in Wt \% of Total Solids. 


\section{LIST OF ACRONYMS/ABBREVIATIONS}

$\begin{array}{ll}\text { AD } & \text { Analytical Development } \\ \text { ARG }-1 & \text { Analytical Reference Glass - 1 } \\ \text { ASP } & \text { Analytical Study Plan } \\ \text { CV-AA } & \text { Cold Vapor - Atomic Absorption Spectroscopy } \\ \text { DWPF } & \text { Defense Waste Processing Facility } \\ \text { IC } & \text { Ion Chromatography } \\ \text { ICP-AES } & \text { Inductively Coupled Plasma - Atomic Emission Spectroscopy } \\ \text { ICP-MS } & \text { Inductively Coupled Plasma - Mass Spectrometry } \\ \text { L } & \text { Liter } \\ \text { M } & \text { Molar } \\ \text { NA } & \text { Not Available (e.g. Not Measured) } \\ \text { RSD } & \text { Relative Standard Deviation } \\ \text { SB4 } & \text { Sludge Batch 4 } \\ \text { SB5 } & \text { Sludge Batch 5 } \\ \text { SRNL } & \text { Savannah River National Laboratory } \\ \text { Std. Dev. } & \text { Standard Deviation } \\ \text { TC } & \text { Total Carbon } \\ \text { TIC } & \text { Total Inorganic Carbon } \\ \text { TS } & \text { Total Solids } \\ \text { WAPS } & \text { Waste Acceptance Product Specifications } \\ \text { Wt \% } & \text { Weight Percent }\end{array}$


Revision 0

This page intentionally left blank. 


\subsection{INTRODUCTION AND BACKGROUND}

A sample of Sludge Batch 5 (SB5) was pulled from Tank 40 in order to obtain radionuclide inventory analyses necessary for compliance with the Waste Acceptance Product Specifications (WAPS) ${ }^{1}$. This sample was also analyzed for chemical composition including noble metals. Prior to radionuclide inventory analyses, a final sample of the H-canyon $\mathrm{Np}$ stream will be added to bound the $\mathrm{Np}$ addition anticipated for Tank 40. The chemical analyses reported here along with the WAPS radionuclide analyses will help define the composition of the sludge in Tank 40 that is currently being fed to DWPF as SB5.

SRNL analyses on SB5 were requested by DWPF via Technical Task Request (TTR) HLW-DWPFTTR-2008- $0010^{2}$. The sample preparation work is governed by Task Technical and Quality Assurance Plan (TTQAP) ${ }^{3}$, and analyses were controlled by an Analytical Study Plan ${ }^{4}$.

One 3-L sample of Tank 40 was pulled on December 3, 2008 following slurry operations. The sample was designated HTF-40-08-157 by H-Tank Farm Operations. Four slurry pumps were started on December 2 and stopped following sixteen hours of operation. The general protocol is for all four slurry pumps to run for eight hours before a DWPF transfer and to be kept running during the transfer, but due to the need to pull a sample, the pumps had to be shut down. The tank level was 170.2 inches after the pumps were secured and when the sample was pulled. The sample was sent to SRNL on December 4, 2008. 
Revision 0

This page intentionally left blank. 


\subsection{APPROACH AND RESULTS}

\subsection{Analytical Methods}

At the Savannah River National Laboratory (SRNL), the 3-L Tank 40 SB5 sample was transferred from the shipping container into a 4-L high density polyethylene vessel and solids allowed to settle overnight. Supernate was then siphoned off and circulated through the shipping container to complete the transfer of the sample. Following thorough mixing of the 3-L sample, a $239 \mathrm{~g}$ sub-sample was removed. This sub-sample was then utilized for all subsequent analytical samples.

Eight separate aliquots of the slurry were digested, four with $\mathrm{HNO}_{3} / \mathrm{HCl}$ (aqua regia ${ }^{5}$ ) in sealed Teflon ${ }^{\circledR}$ vessels and four in $\mathrm{Na}_{2} \mathrm{O}_{2}$ (alkali or peroxide fusion ${ }^{6}$ ) using $\mathrm{Zr}$ crucibles. Due to the use of $\mathrm{Zr}$ crucibles and $\mathrm{Na}$ in the peroxide fusions, $\mathrm{Na}$ and $\mathrm{Zr}$ cannot be determined from this preparation. Additionally, other alkali metals, such as $\mathrm{Li}$ and $\mathrm{K}$ that may be contaminants in the $\mathrm{Na}_{2} \mathrm{O}_{2}$ are not determined from this preparation. Three Analytical Reference Glass $-1^{7}$ (ARG-1) standards were digested along with a blank for each preparation. The ARG-1 glass allows for an assessment of the completeness of each digestion. Each aqua regia digestion and blank was diluted to 1:100 mL with deionized water and submitted to Analytical Development (AD) for inductively coupled plasma - atomic emission spectroscopy (ICP-AES) analysis, inductively coupled plasma - mass spectrometry (ICP-MS) analysis of masses 81-209 and 230-252, and cold vapor atomic absorption (CV-AA) analysis for Hg. Equivalent dilutions of the peroxide fusion digestions and blank were submitted to AD for ICP-AES analysis.

Tank 40 SB5 supernate was collected with a $0.45 \mu \mathrm{m}$ filter cup from a mixed slurry sample in the SRNL Shielded Cells and submitted to AD for ICP-AES. Weighted dilutions of slurry were submitted for ion chromatography (IC), total inorganic carbon/total organic carbon (TIC/TOC), and total base analyses.

\subsection{Results}

Table 2-1 presents the measured SB5 density and weight percent solids data $^{8}$ collected for the SB5 WAPS sample taken in December 2008. Table 2-1 also contains data from the DWPF Sludge Receipt and Adjustment Tank (SRAT) receipt sample data for Batch \#472 as a comparison. Batch \#472 was selected because it was the fifth DWPF batch received from Tank 40 following the start of SB5 processing and both the SRAT heel and receipt material should represent SB5 material. The wt \% total solids for the Tank 40 - WAPS sample is similar to that seen for Batch \#472, and it would be expected to be lower as a result of DWPF pre-concentration of the SRAT batch prior to sampling. The total solids observed for the DWPF SRAT receipt batch should reflect the impacts of the SRAT heel and DWPF pre-sample concentration of incoming Tank 40 transfers. The SRAT heel contributes approximately 13 - $19 \%$ of the volume of slurry in the SRAT vessel and can have total solids in the range of $20 \mathrm{wt} \%$. Calcine factors were also calculated by taking the ratio of the weight percent calcined solids and the weight percent total solids. The Tank 40 - WAPS Sample has a value of 0.79 grams of calcined solids per gram of dried solids. 
Table 2-1. Weight Percent Solids and Density for Tank 40 SB5 Samples and DWPF SRAT Receipt Batch 472 [Number of Samples Included in Average]

\begin{tabular}{|c|c|c|}
\hline Property & $\begin{array}{c}\text { Tank } 40 \text { - WAPS } \\
\text { (\% RSD) }\end{array}$ & $\begin{array}{c}\text { DWPF SRAT } \\
\text { Receipt for } \\
\text { Batch } 472^{\mathrm{a}}\end{array}$ \\
\hline Slurry Density & $1.094(0.6)[4]$ & 1.092 \\
\hline Supernate Density & $1.043(1.0)[4]$ & NA \\
\hline Wt \% Total Solids & $13.36(0.6)[4]$ & 15.51 \\
\hline $\begin{array}{l}\text { Wt \% Calcined } \\
\text { Solids }\end{array}$ & $10.52(0.4)[4]$ & NA \\
\hline $\begin{array}{l}\text { Wt \% Dissolved } \\
\text { Solids }^{\mathrm{b}}\end{array}$ & $4.29(0.9)[4]$ & NA \\
\hline $\begin{array}{l}\text { Wt \% Insoluble } \\
\text { Solids }\end{array}$ & 9.48 & NA \\
\hline $\begin{array}{l}\text { Wt \% Soluble } \\
\text { Solids }^{\mathrm{c}}\end{array}$ & 3.88 & NA \\
\hline
\end{tabular}

Table 2-2 provides the anion results for the Tank 40 WAPS sample and the available DWPF SRAT receipt data for Batch \#472. In order to compare the data from the two labs it was necessary to put the SRNL data on a slurry basis. The supernate sulfur result given for SRNL is calculated from total sulfur detected in the supernate by ICP-AES and is within the lower detection limit for sulfate determined by IC. The Al, B, Ca, Cr, K, Mo, Na, and S values also shown in this table were calculated from the ICPAES data for the supernate and placed on a slurry basis using the insoluble solids content from Table 2-1. Other supernate elements measured were below the ICP-AES detection limits. 
SRNL-STI-2009-00060

Revision 0

Table 2-2. Supernate Analyses for Tank 40 SB5 Samples [Number of Samples Included in Average]

\begin{tabular}{ccccc}
\hline Analyte & $\begin{array}{c}\text { Tank 40 - WAPS } \\
(\mathbf{\%} \text { RSD) } \\
\text { Molar }\end{array}$ & $\begin{array}{c}\text { Tank 40 - WAPS } \\
\mathbf{( \% \text { RSD) }} \\
\mathbf{m g} / \mathbf{k g} \text { slurry }\end{array}$ & Method & $\begin{array}{c}\text { SRAT Receipt for } \\
\text { Batch 472 } \\
\text { mg/kg slurry }\end{array}$ \\
\hline $\mathrm{NO}_{3}{ }^{-}$ & $0.0625(0.3)[4]$ & $7020(0.3)[4]$ & IC & 6680 \\
$\mathrm{NO}_{2}{ }^{-}$ & $0.176(0.5)[4]$ & $3360(0.5)[4]$ & IC & 6540 \\
$\mathrm{SO}_{4}{ }^{2-}$ & $<0.0094$ & $<790$ & IC & 540 \\
$\mathrm{PO}_{4}{ }^{3-}$ & $<0.0038$ & $<310$ & IC & NA \\
$\mathrm{Br}^{-}$ & $<0.0045$ & $<310$ & IC & NA \\
$\mathrm{Cl}^{-}$ & $<0.010$ & $<310$ & IC & NA \\
$\mathrm{CHO}_{2}{ }^{-}$ & $<0.0080$ & $<310$ & IC & 5890 \\
$\mathrm{C}_{2} \mathrm{O}_{4}{ }^{2-}$ & $<0.0041$ & $<310$ & IC & $<510$ \\
$\mathrm{~F}^{-}$ & $<0.019$ & $<310$ & IC & NA \\
$\mathrm{Al}$ & $0.0337(1.0)[4]$ & $858(1.0)[4]$ & ICP-AES & NA \\
$\mathrm{B}$ & $0.000387(1.1)[4]$ & $3.95(1.1)[4]$ & ICP-AES & NA \\
$\mathrm{Ca}$ & $0.000233(38)[4]$ & $8.81(38)[4]$ & ICP-AES & NA \\
$\mathrm{Cr}$ & $0.000225(0.4)[4]$ & $11.1(0.4)[4]$ & ICP-AES & NA \\
$\mathrm{K}$ & $0.00103(1.0)[4]$ & $38.2(1.0)[4]$ & ICP-AES & NA \\
$\mathrm{Mo}$ & $0.0000108(3.5)[4]$ & $0.975(3.5)[4]$ & ICP-AES & NA \\
$\mathrm{Na}$ & $0.655(1.6)[4]$ & $14200(1.6)[4]$ & ICP-AES & NA \\
$\mathrm{S}$ & $0.00610(2.0)[4]$ & $185(2.0)[4]$ & ICP-AES & NA \\
\hline $\mathrm{NA} \equiv \mathrm{Not}$ measured & & & &
\end{tabular}

Table 2-3 provides the total carbon (TC) and total inorganic carbon (TIC) measured for the SB5 WAPS sample. The TIC value measured for SRAT Batch \#472 is only $7 \%$ lower, but no TC value is available for comparison.

Table 2-3. Carbon Analysis for Tank 40 SB5 Samples [Number of Samples Included in Average] (mg C/kg slurry)

\begin{tabular}{|c|c|c|}
\hline Analyte & $\begin{array}{c}\text { Tank } 40 \text { - WAPS } \\
(\% \text { RSD) }\end{array}$ & $\begin{array}{c}\text { SRAT Receipt for } \\
\text { Batch } 472^{\mathrm{a}}\end{array}$ \\
\hline $\begin{array}{l}\text { Total Inorganic } \\
\text { Carbon }\end{array}$ & 833 (4.2) [4] & 775 \\
\hline Total Carbon & $1240(7.4)[4]$ & NA \\
\hline
\end{tabular}

Table 2-4 provides the base measurements made on the SB5 WAPS sample. Total base represents the value determined from an inflection endpoint titration to $\mathrm{pH}$. Free $\mathrm{OH}^{-}$represents the value determined after precipitation of carbonate with $\mathrm{BaCl}_{2}$ and titration to the first inflection endpoint between $\mathrm{pH} 11$ and 8. Further titration of this treated sample to $\mathrm{pH} 7$ yields the value for other base. The total base measured for DWPF Batch \#472 was in reasonable agreement. 
Table 2-4. Base Analysis for Tank 40 SB5 Samples [Number of Samples Included in Average] (mol/kg slurry)

\begin{tabular}{|c|c|c|}
\hline Analyte & $\begin{array}{c}\text { Tank } 40-\text { WAPS } \\
(\% \text { RSD })\end{array}$ & $\begin{array}{l}\text { SRAT Receipt for } \\
\text { Batch } 472^{\mathrm{a}}\end{array}$ \\
\hline Total Base & 0.303 (9.6) [4] & 0.340 \\
\hline Free $\mathrm{OH}^{-}$ & 0.177 (7.4) [4] & NA \\
\hline Other Base & 0.0441 (39) [2] & NA \\
\hline
\end{tabular}

The elemental concentrations determined by ICP-AES, ICP-MS, and CV-AA analyses are presented in Table 2-5. For the Tank 40 - WAPS sample, results from both digestions have been combined where appropriate. Due to the use of $\mathrm{Zr}$ crucibles and $\mathrm{Na}_{2} \mathrm{O}_{2}$ in the alkali fusions, $\mathrm{Zr}$ and $\mathrm{Na}$ values, as well as other alkali metals, were determined from the aqua regia digestion. In the case of B, Mo, Sb, Sn, and V, both preparations yielded values below the detection limits, hence the lowest detection limit value was selected. Alkali fusion data was used to report values for Al, Mg, and Si for the Tank 40 - WAPS sample since the aqua regia preparation fails to dissolve all forms of these elements. ICP-MS analysis of the aqua regia digestion was also used to determine the concentrations of $\mathrm{Cd}, \mathrm{Ce}, \mathrm{Gd}, \mathrm{La}, \mathrm{Pb}$, Th, and $\mathrm{U}$. In the case of Ce the distribution of isotopes was not natural but rather the result of fission product yields from U-235. Hence the sum of the respective isotopic masses was used to determine the reported concentrations for Ce and $U$. The $U$ value reported here from ICP-MS compares to a value determined by ICP-AES of $5.30 \mathrm{wt} \%$ of total solids. For $\mathrm{Cd}, \mathrm{Gd}$, and $\mathrm{Pb}$, the reported value was determined from all measured values calculated using the various isotopes' natural abundance. In the case of La-139 and Th-232, a single isotope has $100 \%$ natural abundance and was used to calculate the values given in the table. 
Table 2-5. Elemental Concentrations* in Tank 40 SB5 Samples in Wt \% of Total Solids (\%RSD) [Number of Samples Included in Average]

\begin{tabular}{|c|c|c|c|}
\hline Element & Tank 40 - WAPS & Element & Tank 40 - WAPS \\
\hline $\mathrm{Al}$ & $9.02(1.5)[4]$ & Mo & $<0.011$ \\
\hline B & $<0.015$ & $\mathrm{Na}$ & $12.2(2.7)[4]$ \\
\hline $\mathrm{Ba}$ & 0.0840 (2.9) [8] & $\mathrm{Ni}$ & $1.87(2.3)[8]$ \\
\hline $\mathrm{Ca}$ & 1.38 (3.8) [8] & $\mathrm{P}$ & 0.160 (15) [7] \\
\hline $\mathrm{Cd}^{\ddagger}$ & 0.0639 (2.9) [4] & $\mathrm{Pb}^{\ddagger}$ & $0.0278(4.9)$ [3] \\
\hline $\mathrm{Ce}^{\ddagger \ddagger}$ & $0.114(0.6)[4]$ & S & $0.254(11)[4]$ \\
\hline $\mathrm{Cr}$ & 0.0550 (5.9) [8] & $\mathrm{Sb}$ & $<0.020$ \\
\hline $\mathrm{Cu}$ & $0.0467(5.7)[8]$ & $\mathrm{Si}$ & 0.912 (1.9) [4] \\
\hline $\mathrm{Fe}$ & 15.0 (2.6) [8] & Sn & $<0.014$ \\
\hline $\mathrm{Gd}^{\ddagger}$ & $0.0609(4.7)[4]$ & $\mathrm{Sr}$ & $0.0461(3.0)[8]$ \\
\hline $\operatorname{Hg} \wedge$ & $1.82(9.4)[4]$ & $\mathrm{Ti}$ & 0.0186 (5.3) [8] \\
\hline K & 0.0494 (1.3) [3] & $\mathrm{Th}^{\ddagger}$ & $0.0636(1.2)[4]$ \\
\hline $\mathrm{La}^{\ddagger}$ & $0.0582(1.0)[4]$ & $\mathrm{U}^{\ddagger \ddagger}$ & $5.02(1.2)[4]$ \\
\hline $\mathrm{Li}$ & 0.0314 (2.2) [8] & V & $<0.017$ \\
\hline Mg & 0.757 (1.7) [4] & $\mathrm{Zn}$ & $0.0431(1.7)[8]$ \\
\hline Mn & 3.48 (3.0) [8] & $\mathrm{Zr}$ & 0.0474 (13) [3] \\
\hline
\end{tabular}

The fission product noble metal and silver concentrations are given in Table 2-6. The values were calculated from ICP-MS data using an Excel spreadsheet. This spreadsheet uses the fission yield for each isotope to account for the mass contribution from isotopes in the tank that could not be measured because isotopes of natural $\mathrm{Cd}$ interfere at this mass. An example of this is the measurement at mass 110 , which is comprised of Pd-110 and Cd-110. The uncertainties were analyzed for the first time using statistical techniques appropriate for replicate measurements of non-highly correlated data. For comparison purposes, unpublished data for the SB5 Confirmation sample (Tank 51 prior to transfer to Tank 40) and the SB4 WAPS (Tank 40) ${ }^{9}$ sample are also given in this table and will be discussed further in the discussion section of this report. 
SRNL-STI-2009-00060

Revision 0

Table 2-6. Noble Metal Fission Products and Silver Concentrations in Tank 40 SB5 WAPS, Qualification and Confirmation Samples in Wt \% of Total Solids (\%RSD)

\begin{tabular}{cccc}
\hline Element & $\begin{array}{c}\text { Tank 40 - SB4 } \\
\text { WAPS }^{9}\end{array}$ & $\begin{array}{c}\text { SB5 Confirmation } \\
\text { Sample }\end{array}$ & $\begin{array}{c}\text { Tank 40 - SB5 } \\
\text { WAPS }\end{array}$ \\
\hline Ag (-107, -109) & $0.00987(0.5)$ & $0.0121(1.3)$ & $0.0102(2.0)$ \\
Pd (-105, -106, -107, -108, -110) & $0.00125(6.0)$ & $0.00321(0.6)$ & $0.00252(3.4)$ \\
Rh (-103) & $0.00840(4.5)$ & $0.0201(3.1)$ & $0.0161(1.1)$ \\
Ru (-101, -102, -104) & $0.0313(0.7)$ & $0.0926(0.8)$ & $0.0733(0.6)$ \\
\hline
\end{tabular}




\subsection{DISCUSSION}

\subsection{Carbonate}

Subtracting the free $\mathrm{OH}^{-}$and other base values from the total base measurement should yield the carbonate contribution to the base equivalents. The carbonate contribution determined from the titration measurements is $0.082 \mathrm{~mol}$ carbonate/kg slurry. This compares to a carbonate concentration via the TIC measurement of $0.069 \mathrm{~mol}$ carbonate/kg slurry. The agreement is good considering the large uncertainty in determining carbonate via titration.

\subsection{Anion Comparison}

A comparison of anion data, shown in Table 2-2, for this sample and the DWPF SRAT Receipt Batch \#472 is difficult due to a number of factors. The DWPF SRAT receipt nitrite ion concentration would be expected to be reduced relative to the incoming sludge since the heel in the SRAT is reduced in nitrite ion. Similarly, the SRAT formate and nitrate ion concentration would be expected to be elevated relative to the sludge since the heel in the SRAT is greatly increased in these anions. The nitrite to nitrate ratio observed is considerably different, but is likely due to the large residual heel in the SRAT vessel and the concentration of DWPF SRAT receipt material prior to sampling. This pre-concentration of the SRAT receipt material, prior to sampling and analysis, makes a comparison of anion levels very difficult for this sludge batch. Previous new sludge batches have been higher in incoming insoluble solids and did not require this pre-concentration boil prior to routine SRAT processing.

\subsection{Sulfur}

The conversion of the total supernate sulfur values, as shown in Table 2-2, from molar to wt\% of total solids, yields $0.127 \mathrm{wt} \% \mathrm{~S}$ for the Tank 40 - SB5 WAPS sample. Comparing this value with the total slurry sulfur value in Table $2-5$ indicates that $50 \%$ of the sulfur in the WAPS sample is insoluble. For $\mathrm{SB}^{10}$ and SB $4^{11}, 95 \%$ and $93 \%$ of the sulfur was soluble, respectively. Hence, this is the first time that a major fraction of the sulfur has been found in the insoluble solids fraction of a sludge batch. Since the total sulfur content does not exceed any glass limits, there should not be any negative consequences to the speciation of the sulfur in SB5. When the SB5 WAPS supernate sulfur value by ICP-AES (Table $2-2$ ) is put on a slurry sulfate basis, the result is $509 \mathrm{mg}$ sulfate/kg slurry. This compares well with the DWPF sulfate analysis for Batch \#472 of $540 \mathrm{mg}$ sulfate/kg slurry.

\subsection{Elemental Ratios}

A comparison of the elemental ratios of the major insoluble solids using data from Table 2-5 is given in Table 3-1. SRAT Receipt Batch \#472 data is from DWPF and was used to calculate the ratios of Fe to $\mathrm{Al}, \mathrm{Ca}, \mathrm{Mn}$, and $\mathrm{U}$. These ratios should remain constant through batch processing unless an addition of material containing one or more elements of interest is made. Generally, the elemental ratios observed for SB4 and SB5 are very similar for these major elements. The agreement between the Tank $40-$ WAPS sample and the DWPF Batch \#472 data is more variable. The Mn/Fe and U/Fe ratios look good and there was agreement with data for other DWPF batches. The Al/Fe ratio discrepancy is probably due to our use of a DWPF Al value resulting from cold chemical digestion method that is known to be biased low for $\mathrm{Al}$ when the $\mathrm{Al}$ is present as boehmite. At the time of this report, the DWPF $\mathrm{Al}$ value determined from their alkali fusion data for the first 10 SRAT receipt batches was not available. The $\mathrm{Ca} / \mathrm{Fe}$ ratio measured for other DWPF SB5 batches showed less difference from the WAPS sample, generally around $10 \%$ low, as compared to the $18 \%$ discrepancy for Batch \#472. The cause of the low Ca measurements is unclear but appears to be improving in later SRAT batches. 
SRNL-STI-2009-00060

Revision 0

Table 3-1. Comparison of Elemental Ratios for Major Insoluble Elements in the Tank 40 SB4 and SB5 Samples with DWPF Batch 472 SRAT Receipt Data

\begin{tabular}{ccccc}
\hline Element Ratio & $\begin{array}{c}\text { Tank 40 - SB4 } \\
\text { WAPS }\end{array}$ & $\begin{array}{c}\text { Tank 40 - SB5 } \\
\text { WAPS }\end{array}$ & $\begin{array}{c}\text { DWPF SRAT } \\
\text { Receipt } \\
\text { Batch 472 }\end{array}$ & $\begin{array}{c}\text { \% Difference } \\
\text { SB5 WAPS - } \\
\text { Batch 472 }\end{array}$ \\
\hline $\mathrm{Al} / \mathrm{Fe}$ & 0.67 & 0.60 & 0.47 & 27 \\
$\mathrm{Ca} / \mathrm{Fe}$ & 0.099 & 0.092 & 0.078 & 18 \\
$\mathrm{Mn} / \mathrm{Fe}$ & 0.22 & 0.23 & 0.23 & -2 \\
$\mathrm{U} / \mathrm{Fe}$ & 0.37 & 0.33 & 0.32 & 5 \\
\hline
\end{tabular}

\subsection{Noble Metal Ratios}

A comparison of the fission yield ratios for $\mathrm{Ru}: \mathrm{Rh}, \mathrm{Ru}: \mathrm{Pd}$, and $\mathrm{Ru}$ :Ag with those measured for the Tank 40 - SB5 WAPS sample is provided in Table 3-2. The Tank 40 SB4 WAPS and Tank 51 SB5 Confirmation samples results are also provided for comparison. The ratios are based upon Ru due to its relatively high concentration in the sludge as compared with the other noble metals. The Ru:Rh ratio agrees reasonably well for all three samples, while the Ru:Ag ratios differ significantly from the fission yield ratios. This lack of agreement for the Ag ratios is not unexpected since the majority of the Ag is natural Ag originating from Ag saddles used in the dissolvers to scavenge radioactive iodine, while the noble metals are fission products of U-235. Consequently the relative concentration of $\mathrm{Ag}$ is not expected to be in proportion to the fission yields of its two isotopes. The Ru:Pd ratios agree amongst the three samples but not with that predicted by the fission yield. A possible explanation for this is that a portion of the Pd is soluble and hence has fractioned off into the salt waste, thus increasing the ratio of $\mathrm{Ru}$ to $\mathrm{Pd}$ in the sludge waste.

Table 3-2. Fission Yield Ratios and Measured Noble Metal Ratios in Various SB4 and SB5 Samples

\begin{tabular}{ccccc}
\hline Ratio & Fission Yield & $\begin{array}{c}\text { Tank 40 - SB4 } \\
\text { WAPS }^{\mathbf{9}}\end{array}$ & $\begin{array}{c}\text { Tank 51 - SB5 } \\
\text { Confirmation Sample }\end{array}$ & $\begin{array}{c}\text { Tank 40 - SB5 } \\
\text { WAPS }\end{array}$ \\
\hline Ru:Rh & 3.7 & 3.7 & 4.6 & 4.6 \\
Ru:Pd & 6.9 & 25 & 29 & 29 \\
Ru:Ag & 342 & 3.2 & 7.7 & 7.2 \\
\hline
\end{tabular}

9 Bannochie, C. J., Tank 40 Final SB4 Chemical Characterization Results, WSRC-STI-2007-00674, Savannah River Site, Aiken, SC 29808 (2008).

The SB5 WAPS sample in Tank 40 was comprised of a blend of the Tank 51 SB5 Confirmation sample material and the heel of the SB4 WAPS sample remaining in Tank 40. Taking the SB5 plant projected blend of two-thirds of Tank 51 and one-third of Tank 40, the noble metal concentrations of the final SB5 WAPS sample can be predicted and the values obtained are shown in Table 3-3. There is excellent agreement between the values predicted by the blend ratio from the measurements made on the two previous samples and those measured on the final SB5 WAPS sample. The fact adds confidence to the consistency of the measurements, if not the accuracy of the results that have been reported for noble metal content of DWPF sludge materials. 
SRNL-STI-2009-00060

Revision 0

Table 3-3. Predicted versus Measured SB5 WAPS Noble Metal Concentrations in Wt \% of Total Solids

\begin{tabular}{ccc}
\hline Element & $\begin{array}{c}\text { Tank 40 - SB5 WAPS } \\
\text { Predicted }\end{array}$ & $\begin{array}{c}\text { Tank 40 - SB5 WAPS } \\
\text { Measured }\end{array}$ \\
\hline Ag & 0.0114 & 0.0102 \\
Pd & 0.00256 & 0.00252 \\
Rh & 0.00162 & 0.00161 \\
Ru & 0.0722 & 0.0733 \\
\hline
\end{tabular}


Revision 0

This page intentionally left blank. 


\subsection{CONCLUSIONS}

- The elemental ratios of the major elements for the SB5 WAPS sample, whose major Tank 51 Qualification sample component underwent Al dissolution, are similar to those measured for the SB4 WAPS sample.

- The elemental composition of this sample and the analyses conducted here are reasonable and consistent with DWPF batch data measurements in light of DWPF pre-sample concentration and SRAT product heel contributions to the DWPF SRAT receipt analyses.

- Fifty percent of the sulfur in the SB5 WAPS sample is insoluble, and this represents a significantly larger fraction than that observed in previous sludge batches.

- The noble metal and Ag concentrations predicted from the measured values for the Tank 51 Confirmation sample and Tank 40 SB4 WAPS sample using the two-thirds Tank 51, one-third Tank 40 heel blend ratio used to arrive at SB5, agree with the values for the Tank 40 SB5 WAPS sample measured for this report. 
Revision 0

This page intentionally left blank. 


\subsection{REFERENCES}

${ }^{1}$ Office of Environmental Restoration and Waste Management, Waste Acceptance Product Specifications for Vitrified High-Level Waste Forms, US DOE Document DOE/EM-0093, Rev. 2, (12/96).

${ }^{2}$ Fellinger, T. L. Sludge Batch 5 SRNL Shielded Cells Testing, HLW-DWPF-TTR-2008-0010, Rev. 2, Savannah River Site, Aiken, SC 29808 (2008).

${ }^{3}$ Bannochie, C. J., Pareizs, J. M. Qualification of DWPF Sludge Batch 5 in the SRNL Shielded Cells: Task Technical and Quality Assurance Plan, WSRC-RP-2008-00137, Rev. 2, Savannah River Site, Aiken, SC 29808 (2008).

${ }^{4}$ Bannochie, C. J., Pareizs, J. M. Qualification of DWPF Sludge Batch 5 in the SRNL Shielded Cells: Analytical Study Plan, WSRC-RP-2008-00138, Rev. 2, Savannah River Site, Aiken, SC 29808 (2008).

${ }^{5}$ Coleman, C. J. Aqua Regia Dissolution of Sludge for Elemental Analysis, Manual L16.1, Procedure ADS-2226, Rev. 7, Savannah River Site, Aiken, SC 29808 (2008).

${ }^{6}$ Coleman, C. J. Alkali Fusion Dissolutions of Sludge and Glass for Elemental and Anion Analysis, Manual L16.1, ADS-2502, Rev. 6, Savannah River Site, Aiken, SC 29808 (2008).

7 Smith, G. L. Characterization of Analytical Reference Glass - 1 (ARG-1), PNL-8992, Pacific Northwest (National) Laboratory, Richland, WA (1993).

${ }^{8}$ Marek, J. C., Correction Factor for Soluble and Insoluble Solids, SRTC-PTD-92-0040, Savannah River Site, Aiken, SC 29808 (1992).

${ }^{9}$ Bannochie, C. J., Tank 40 Final SB4 Chemical Characterization Results, WSRC-STI-2007-00674, Savannah River Site, Aiken, SC 29808 (2008).

${ }^{10}$ Bannochie, C. J., Fellinger, T. L, and Pareizs, J. M. Tank 40 Final SB3 Chemical Characterization Results, WSRC-TR-2005-00049, Savannah River Site, Aiken, SC 29808 (2005).

${ }^{11}$ Bannochie, C. J. Tank 40 Final SB4 Chemical Characterization Results, WSRC-STI-2007-00674, Savannah River Site, Aiken, SC 29808 (2008). 
SRNL-STI-2009-00060

Revision 0

This page intentionally left blank. 


\subsection{ACKNOWLEDGEMENTS}

The author would like to acknowledge the support of the SRNL Shielded Cells technicians and supervision. Additionally, we would like to thank Tommy Edwards (SRNL-SCS) for useful discussions and guidance in the calculation of silver and noble metal concentration standard deviations. 


\section{Distribution:}

S. L. Marra, 773-A

A. B. Barnes, 999-W

D. A. Crowley, 773-43A

S. D. Fink, 773-A

C. W. Gardner, 773-A

B. J. Giddings, 786-5A

C. C. Herman, 999-W

F. M. Pennebaker, 773-42A

J. P. Vaughan, 773-41A

D. J. McCabe, 773-42A

D. K. Peeler, 999-W

M. E. Stone, 999-W

N. E. Bibler, 773-A

J. M. Pareizs, 773-A

D. C. Koopman, 999-W

J. E. Occhipinti, 704-S

D. C. Sherburne, 704-S

J. W. Ray, 704-S

H. J. Kunis, 704-S

A. J. Cross, 704-71S

J. F. Iaukea, 704-30S

M. A. Broome, 704-29S

R. T. McNew, 704-27S

A. R. Shafer, 704-27S

M. C. Clark, 704-27S

J. M. Bricker, 704-27S

T. L. Fellinger, 704-26S

H. H. Elder, 704-24S

H. B. Shah, 766-H

J. M. Gillam, 766-H

B. A. Hamm, 766-H

D. D. Larsen, 766-H 